\title{
MONITORING AND PHYSICO-CHEMICAL ASSESSMENT OF EX- MINING POOLS IN PERAK, MALAYSIA
}

\author{
Danial Qadir*1, Hilmi Mukhtar ${ }^{1}$, Lau Kok Keong ${ }^{1}$ \\ ${ }^{1,2,3}$ Universiti Teknologi PETRONAS, Department of Chemical Engineering, Bandar Sri Iskandar, 32610, Perak, \\ Malaysia \\ *Corresponding author: danial2715@gmail.com \\ Received: 4 May $2016 \quad$ Revised: 21 Dec $2016 \quad$ Accepted: 27 Feb 2017
}

\begin{abstract}
Monitoring and Physico-chemical characterization of ex-mining pools was carried out for 9 months at 15 days interval. Physico-chemical parameters such as $\mathrm{pH}$, electrical conductivity, total suspended solids (TSS), total dissolved solids (TDS), chemical oxygen demand (COD), hardness as well as anions including chloride, nitrate, phosphate, sulfate and cations such as calcium, magnesium, tin, lead, iron, nickel, chromium, zinc were investigated. A comparison was also made to National Drinking Water Quality Standards Malaysia (NDWQSM). It was determined that only turbidity, COD and cations exceeded the standard limits set for drinking water. Other parameters such as $\mathrm{pH}$, electrical conductivity, anions and hardness remained within the allowable limits during the sampling period. It is revealed that COD values (up to $180 \mathrm{mg} / \mathrm{L}$ ) were found above the permissible limits $(10 \mathrm{mg} / \mathrm{L}$ ). Moreover, among all cations investigated here, lead (up to $0.19 \mathrm{mg} / \mathrm{L}$ ), nickel (up to $0.05 \mathrm{mg} / \mathrm{L}$ ) and iron (up to $1.286 \mathrm{mg} / \mathrm{L}$ ) were present in hazardous amount whereas tin was noted to be $25 \mathrm{mg} / \mathrm{L}$. It was deduced that these ex-mining pools could be a potential fresh water resource only after suitable treatment such as membrane filtration and adsorption could be applied to remove the contaminants and heavy metals.
\end{abstract}

KEYWORDS Ex-mining pools, Heavy metals, Water characterization, Tin, Lead

\section{INTRODUCTION}

Water is indispensable for all forms of life. It is needed in almost all human activities. Access to safe freshwater is now regarded as a universal human right by UNDP (WHO G. 2011). Main water resources are natural water (snow, rain etc.) surface water, ground water, sea water, brackish water and treated water. Water use is impacted and polluted by climate change and more importantly by changes in population, lifestyle, economy, and technology; in particular by food demand, which drives irrigated agriculture, globally, the largest water-use sector (Kundzexicz Z. 2008; Tansel B.2008). Contaminations of water resources could be of chemical, physical, biological or radioactive type (WHO G. 2011; Tansel B. 2008; Ramalho R. 2012).

It is estimated that globally 1.1 billion people have no access to potable water supply, unfortunately two third (almost 670 million) of this staggering figure belongs to Asian region (Pimentel D., 1997). Malaysia is a water rich country whose socio-economic development is dependent on fresh water resources (Abidin Z. R. Z. 
2004). Table $1 \& 2$ show the water resources currently available in Malaysia and the pollution sources respectively. It is opined that $97 \%$ of raw water originates from surface water resources (for domestic, industrial and agricultural purposes). Nevertheless, $60 \%$ of Malaysian surface water is eutrophic (i.e. containing nitrates and phosphates) due to agricultural activities (Zakria S. 2004; Husaini A. 2012). Additionally, river water may also be polluted from $30 \%$ to $100 \%$ due to discharge of heavy metals ions, pathogens and hazardous industrial wastes in it (Hinrichsen D. 2002).

Table 1: Water resources in Malaysia [8]

\begin{tabular}{cc}
\hline Water Resources & Quantity $\left(\right.$ Billion-m $\left.^{\mathbf{3}}\right)$ \\
\hline Annual Rainfall & 990 \\
Evapo-transpiration & 360 \\
Ground water recharges & 566 \\
Surface run off & 64 \\
Surface artificial storage & 25 \\
Ground water storage & 5000 \\
\hline
\end{tabular}

Table 2: Sources of drinking water pollution in Malaysia [7]

\begin{tabular}{cc}
\hline Sources of pollution & Percentages (\%) \\
\hline Industry & 92 \\
Development & 77 \\
Household & 58 \\
Agriculture & 43 \\
Livestock Farming & 43 \\
\hline
\end{tabular}

Malaysia is one of the countries which are immensely affected by water scarcity. It is an established fact that urbanization, industrialization and climate changes have seriously posed threats to its current water resources, hence insisting the immediate 
need for finding alternative resources (Hock L. C. 2008). Malaysia has been one of the biggest exporters (up to $40 \%$ ) of tin in past (Lau R. 1999). In Malaysia, Perak was one of the states which was famous for its tin production contributing to tin exports around 63\% (Ang L. H.1994). Since the tin industry in Malaysia is diminished, these abandoned mining sites have emerged as a serious threat to the natural habitats due to presence of excessive heavy metals (arsenic, lead, tin, nickel etc.) in it (Alshaebi F. Y. 2009). These mining sites are turned into mining pools because of storage of rainwater in them. Currently, it is believed that there are 4300 mining pools present in peninsular Malaysia (Arumugam P. T. 1994; Yusoff F. 2006; Ang L. 2002) and only few of them are being used as alternate water resources while others are either kept idle or being used as recreational sites (Orij K. 2013; Yusof A. 2001). Hence ex-mining pools could be a natural available resource to meet the local needs, if treated and managed properly.

The objective of this project was to characterize the water quality of these exmining pools and to investigate the effects of seasonal variations on it. All the pools reported in this paper are located in Perak, Malaysia. Physico-chemical characterization is reported in this research which could be useful for selection of appropriate treatment method hence exploiting these pools as fresh water sources.

\section{METHODOLOGY}

\subsection{Samples and Standards: Water} samples were collected from five different ex-mining pools. These pools were labelled as EP1, EP2, EP3, EP4 and EP5 and their coordinates are given in Table 3. These samples were collected over the period of nine months (255 days) from April 15, 2014 to December 31, 2014 with 15 days interval time. Sample collection was carried out by a plastic bucket attached to a 3 metre long string. This bucket was thrown into the water while standing on the bank of the pools. Three samples were taken from each lake at different locations. The estimated depth of the samples was 3 metre and the sampling distance from the bank was 5 metre. These samples were then filled in 1 litre polyethylene sample bottles. All instruments and equipment used for analysis were washed and rinsed with deionized water before their use. All the reagents used were of analytical grade. Values for each parameter presented here are average of three samples for each lake. Analyses were carried out following the American Public Health Association (APHA) standard methods (APHA 1976). 
Table 3: Coordinates of ex-mining pool investigated

\begin{tabular}{ccc}
\hline Pool Label & \multicolumn{2}{c}{ Coordinates } \\
\hline EP1 & 4.384337 & 100.973877 \\
EP2 & 4.384400 & 100.978759 \\
EP3 & 4.381593 & 100.978200 \\
EP4 & 4.383626 & 100.974735 \\
EP5 & 4.381161 & 100.975872 \\
\hline
\end{tabular}

1.2. Methods: All the parameters except $\mathrm{pH}$ and temperature were investigated at room temperature $\left(25 \pm 1^{\circ} \mathrm{C}\right)$. Samples were brought to the laboratory after collection for further analyses. Temperature, $\mathrm{pH}$, conductivity and total dissolved solids were measured by EUTECH (Cyberscan CON-11). While total suspended solids were determined following the standard method No. 2540 D in the laboratory. Turbidity measurements were taken by (HACH-2100Q) standard method (APHA-2130). Chemical oxygen demand (COD) was investigated using HACH method (standard method 5220-D) by using HACH/DRB-200 for digestion and DR-500 spectrophotometer. Cations and heavy metals in water samples were identified by the Polarized Zeeman atomic absorption spectrophotometer (HITACHI/Z-5100). Water hardness of all the pools was calculated following the APHA method $2340 \mathrm{~B}$, on the basis of calcium and magnesium ions as detected in pool water Anions in water samples were determined by anion exchange chromatograph 761- compact IC (METROHM). Table 4 highlights the parameters and abbreviations along with the units for these parameters which were used in this study for physicochemical characterization of ex-mining pools. 
Table 4: List of Parameters and Their Abbreviations and Units Used In Present Study

\begin{tabular}{ccc}
\hline Parameter & Abbreviation & Unit \\
\hline Electrical Conductivity & EC & $\mu \mathrm{S} / \mathrm{cm}$ \\
Total Dissolved Solids & TDS & $\mathrm{mg} / \mathrm{L}$ \\
Total Suspended Solids & TSS & $\mathrm{mg} / \mathrm{L}$ \\
Turbidity & - & $\mathrm{NTU}$ \\
Chemical Oxygen Demand & $\mathrm{COD}$ & $\mathrm{mg} / \mathrm{L}$ \\
Hardness & - & $\mathrm{mg} / \mathrm{L} \mathrm{of} \mathrm{CaCO} 3$ \\
Anion and Cations & - & $\mathrm{mg} / \mathrm{L}$ \\
\hline
\end{tabular}

\section{RESULTS AND DISCUSSION}

i. Temperature and $\mathbf{p H}$ :

Temperatures and $\mathrm{pH}$ for all the samples were recorded at set intervals of 15 days on site. Temperature of studied ex-mining pools is assessed to be $29 \pm 2{ }^{\circ} \mathrm{C}$ during the monitoring tenure. It is observed that $\mathrm{pH}$ for these ex-mining pools remained within range of $6.5-8.5$ as defined by Malaysian drinking water standards (DWQSM 2010). This study revealed that ex-mining pools (EP1 and EP2) remained of slightly alkaline nature throughout the sampling tenure while their value varied from 7 to 8 $( \pm 0.1)$. However, EP3, EP4 and EP5 showed both slightly acidic and slightly alkaline characters during the sampling term where $\mathrm{pH}$ values for aforementioned ex-mining pools ranged from 6.5 - 7.66, $6.51-7.11$ and $6.4-7.07$ respectively. Figure 1 presents the monitoring data for 255 days sampling tenure. From the monitoring, it is concluded that for the investigated mining pools no significant changes in $\mathrm{pH}$ occurred over the sampling period. Moreover, ex-mining pools were in neutral range with slight variations (alkaline/acidic) in their nature only. Since $\mathrm{pH}$ of water is of great concern due to changes in its taste so it should be carefully considered when employing this water for drinking purposes. 

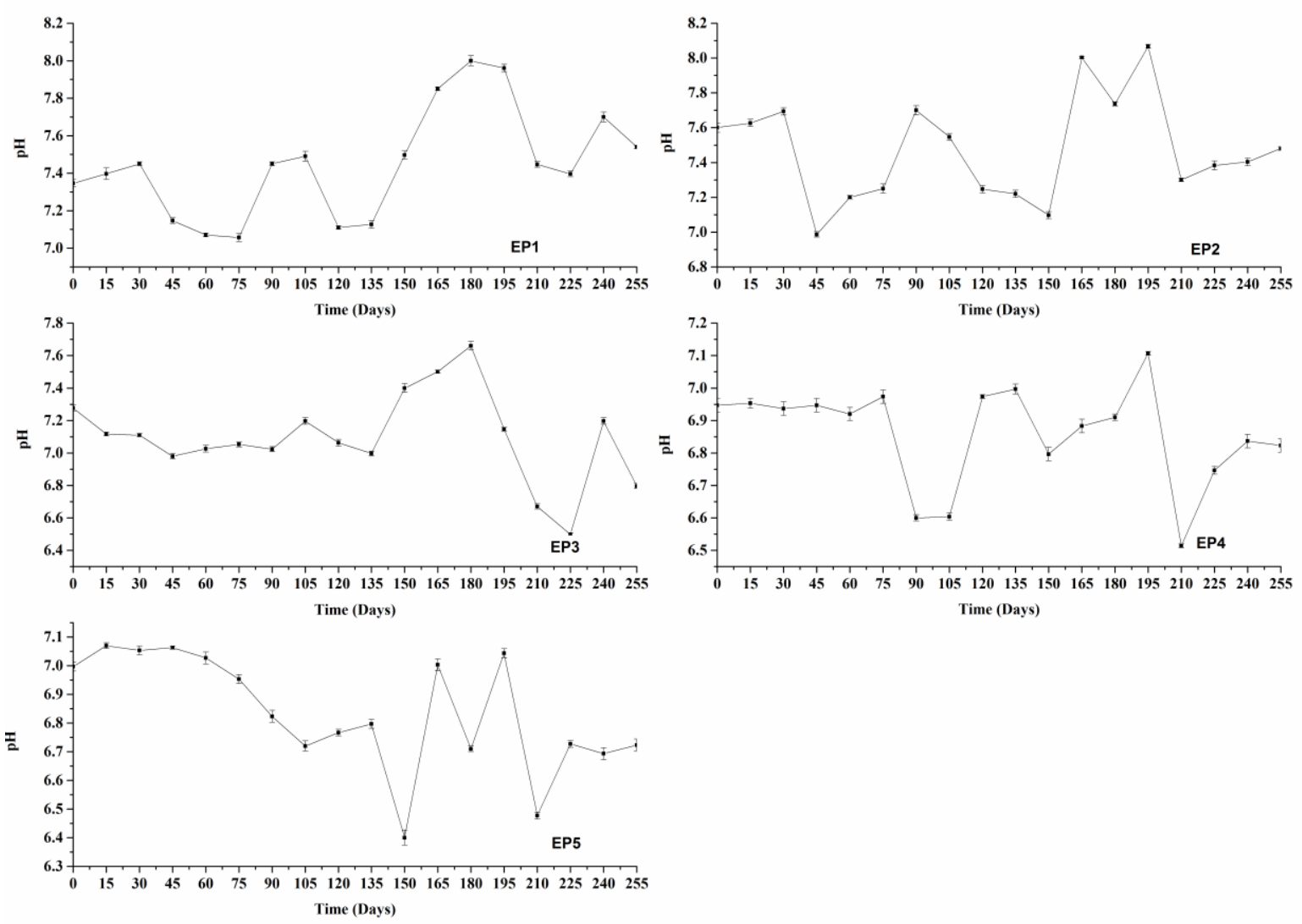

Time (Days)

Figure 1: $\mathrm{pH}$ monitoring of ex-mining pools (EP1, EP2, EP3, EP4 and EP5)

\section{ii. Total Suspended Solids}

(TSS): It is determined that total suspended solids (TSS) values for all the pools remained within $100 \mathrm{mg} / \mathrm{L}$ except EP5, for which TSS value hyped up to 193 $\mathrm{mg} / \mathrm{L}$. For dry periods, such as for days 15 and 60, suspended values for this pool (EP5) decreased notably. Increase in suspended solids concentration is suspected due to the turbulence and inclusion of drainage by rainfall water from forest in the periphery of lake which also added the mineral content in it
(Zalifah M. 2007). This drainage contained slit, clay, sand particles from nearby construction site which caused this hype in total suspended value for EP5 on sampling day (120). Same behavior of wet and dry seasons for TSS values has also been previously reported where inclusion of organic/inorganic materials through vicinity, also turbulence due to rain caused higher TSS values for these pools (Makwe E. 2013; Meme F. K. 2014). Figure 2 gives a trend of sampling tenure for total suspended solids of all five pools. 


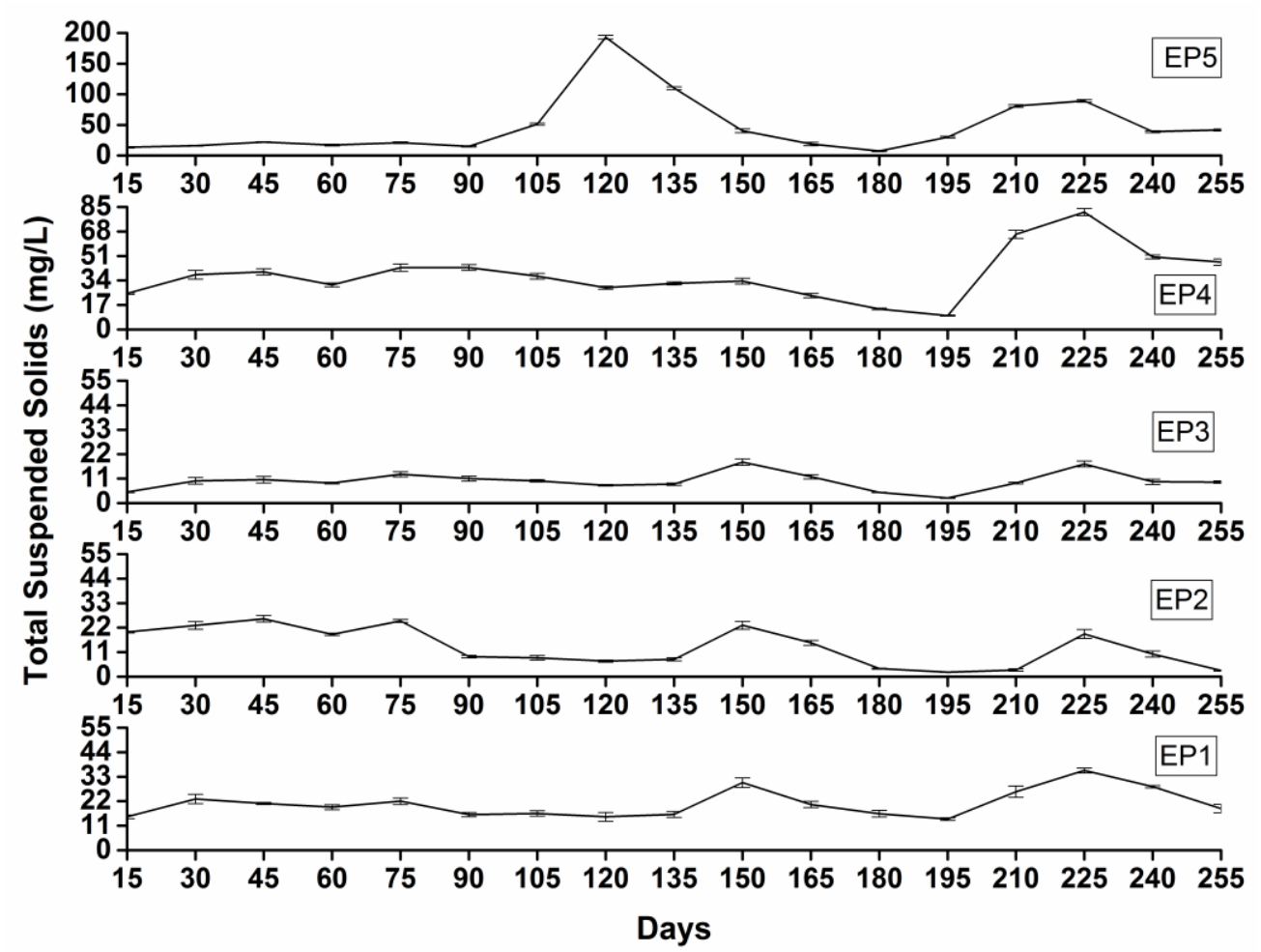

Figure 2: TSS monitoring of ex-mining pools (EP1, EP2, EP3, EP4 and EP5)

iii. Total Dissolved Solids (TDS) / Electrical Conductivity (EC):

For all pools, total dissolved solids were determined in terms of EC values. These values were noted to be under allowable limits over the whole sampling tenure. Since, these pools are of mining site, heavy metal ions along with sodium, calcium and magnesium ions are susceptible to be the main cause of dramatic changes in EC values during sampling tenure. It is believed that during the rain, seepage of metal ions from nearby soil as well as the inclusion of runoff water from periphery of pools mainly caused the dramatic change in the ex-mining pools EC values (Makwe E. 2013; Meme F. K. 2014). The standard value as defined by National Drinking Water Quality Standards Malaysia (NDWQSM) is $1000 \mu \mathrm{S} / \mathrm{cm}$ respectively (DWQSM 2010). Figure 3 shows the variations noticed during the sampling time. All the ex-mining pools demonstrated the same pattern over the monitoring period except (EP1), which had quite consistent behavior for sampling period and no abrupt changes were observed here. Maximum dissolved solids value (300 $\mathrm{uS} / \mathrm{cm}$ ) was noted for ex-mining pool (EP2) to the end of sampling tenure owing to additional factors such as human recreational activity resulting in contamination of this pool. 


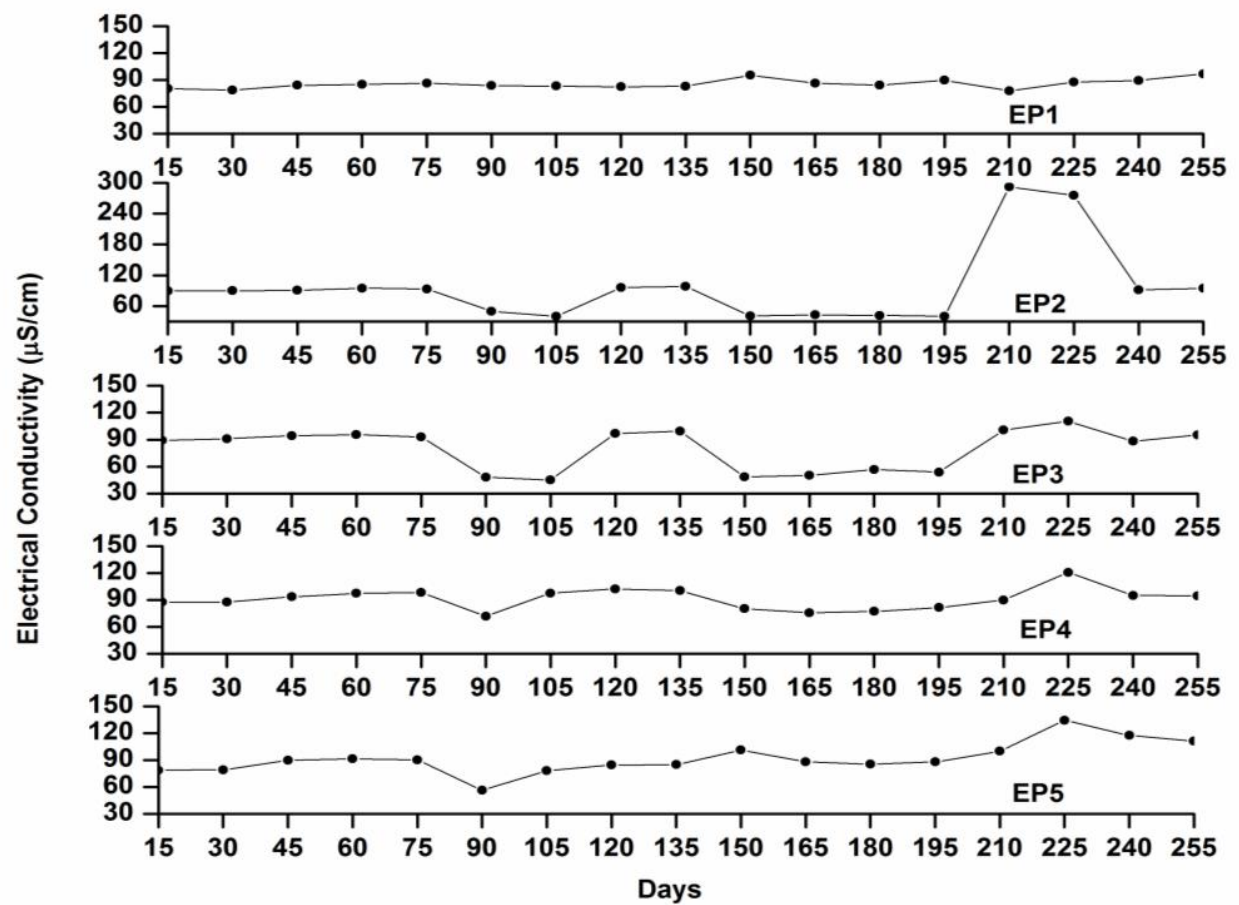

Figure 3: EC monitoring of ex-mining pools (EP1, EP2, EP3, EP4 and EP5)

iv. Turbidity: Studies reveal that pools such as EP1, EP3, EP4 have turbidity values greater than the standard value given by NDWQSM value i.e. 5NTU (DWQSM 2010). Turbidity is witnessed to make pool water cloudy especially during the rainy times. Inclusion of drainage from nearby forest is considered a main factor by bringing the slit, clay and organic matter (e.g. leaves dead insects or animals etc.) (Zalifah M. 2007; Post D. 1995). Among all pools studied here, EP5 showed a dramatic increase in turbidity at sampling day (120) which is attributed to the addition of excessive clay, slit or soil from nearby construction site and peripheral forest. Drain of construction site was directly dumped into EP5 turning it into opaque water body with highest turbidity around 480NTU. Other ex-mining pools (EP1, EP2, EP3, EP4) behaved in a same trend during the rainy season except sampling days 150 to 165 , where a significant rise in turbidity was observed for these pools. It is observed that aforementioned external factors played a major part in this trendy behavior of turbidity values here. Figure 4 here projects the trend of turbidity during the sampling period. 


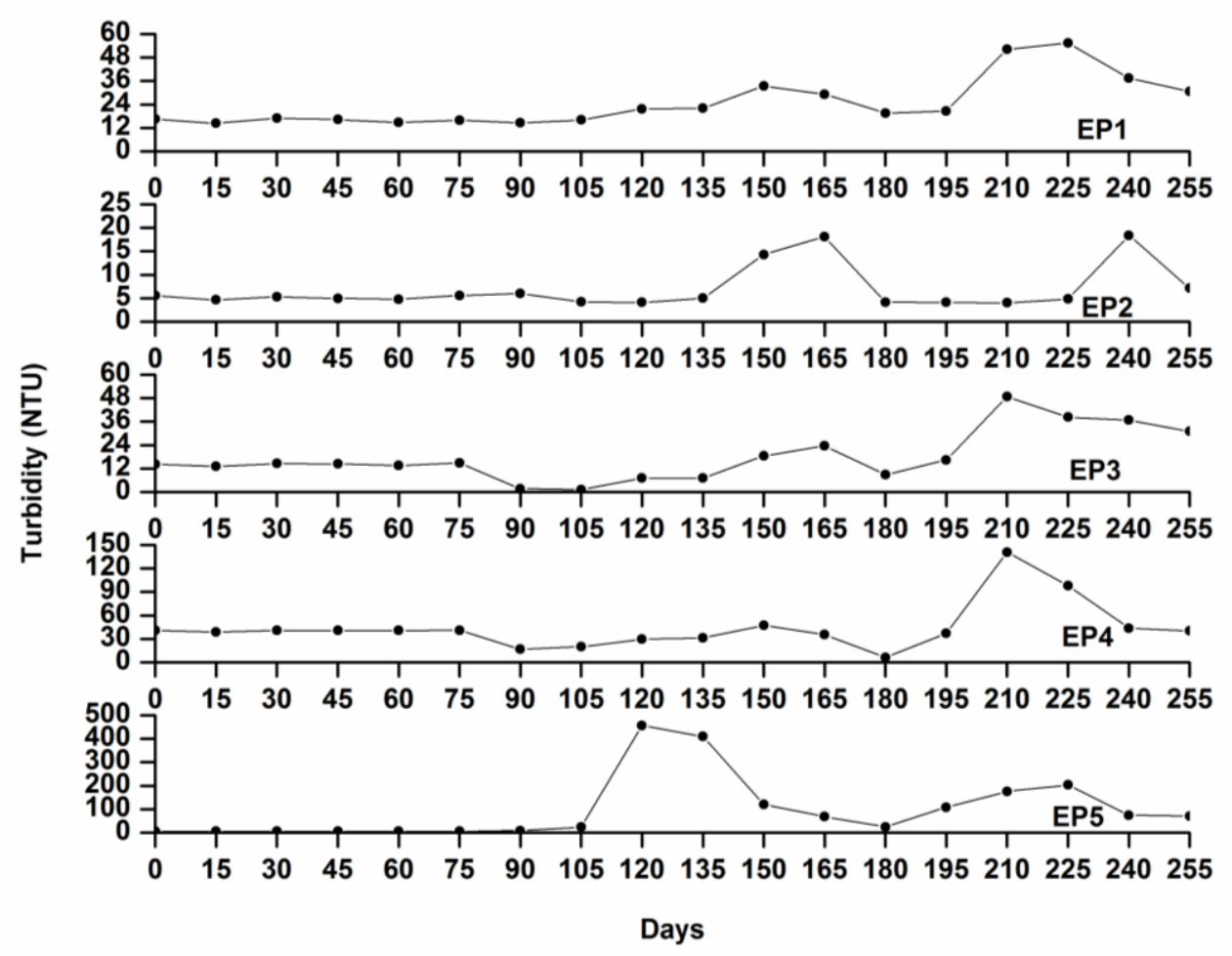

Figure 4: Turbidity monitoring of ex-mining pools (EP1, EP2, EP3, EP4 and EP5)

\section{v. Chemical Oxygen}

Demand (COD): Results have shown that all pools have COD values above allowable limit (10 $\mathrm{mg} / \mathrm{L})$ by NDWQSM (DWQSM 2010). The likely reason for this could be the presence of organic compounds. These organic compounds are suspected to be the result of runoff water, seepage from soil and human activity e.g. (dumping of food, drinks and garbage etc.) Moreover, addition of dead plants due to drainage water from nearby forest and growth of aquatic life (catfish, tilapia etc.) in pools could also be the likely reason for increased COD values (Vega M. 1998;

vi.

\begin{abstract}
Azizullah A.2011). Trend of COD variation over sampling tenure is presented in figure 5 here. Among all pools, EP4 showed significantly higher values of COD of $180 \mathrm{mg} / \mathrm{L}$ but it decreased gradually until sampling day 210 when it increased again up to $50 \mathrm{mg} / \mathrm{L}$. For, all other pools e.g. EP1, EP2, EP3 and EP5, COD values remained in the range of $20-80(\mathrm{mg} / \mathrm{L})$. No specific pattern was noted for these pools since aquatic life and human activity around the pools might have played vital role for this unpredictable behavior along with seasonal effects.
\end{abstract}




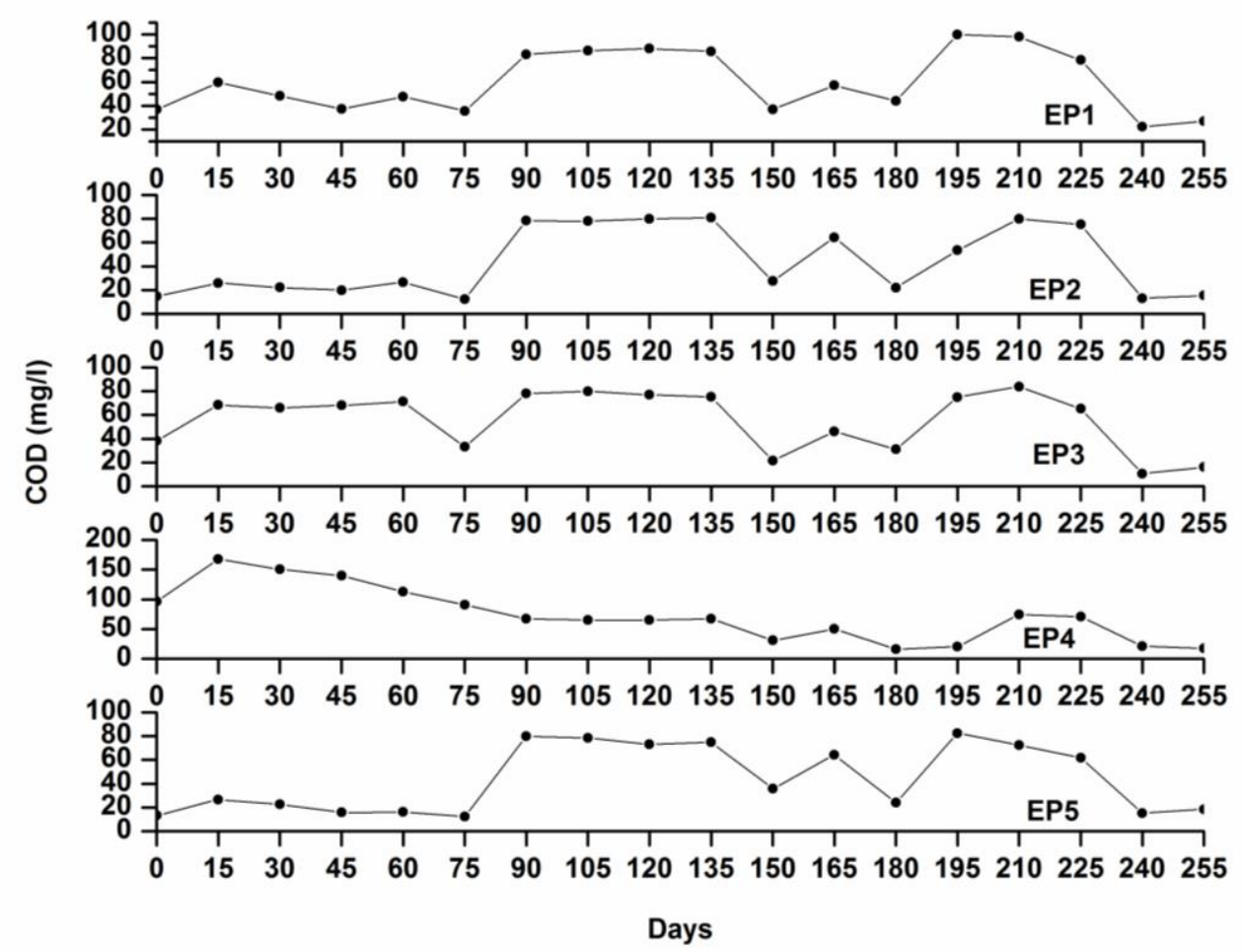

Figure 5: COD monitoring of ex-mining pools (EP1, EP2, EP3, EP4 and EP5)

\section{vii. Cations and Anions}

Presence of cations in ex-mining pools was identified since these ions could immensely affect the water quality and aquatic life in it. Sources of these ions in water bodies could be the result of either direct such as dumping of waste, drainage etc. or indirect source such as human activity, soil chemistry etc. (Mumtaz M. 2010). Many cations including heavy metals were tested in pool water samples. Cations such as tin, lead, magnesium, calcium, sodium, iron, nickel, chromium and zinc were investigated. Anions present in the pool water were also noted above the standard values. It is believed that presence of nitrate in pool waters is either due to runoff from nearby plantation or decomposition of nitrogenous organic compounds have raised the level of nitrates in these pools. Inclusion of nitrogenous compounds is suspected because of frequent recreational human activity around the pools. Phosphate in all other pools except EP1 is not detected. Presence of phosphate in EP1 is suggested to be the inclusion of detergent from the periphery since occasional washing activity in open area around pool is noticed. It is noted that all ex-mining pools showed significant quantity of sulphate and chlorides ions in them, which is thought to be the direct result of soil morphology e.g. gypsum, limestone and 
saline or brackish nature of water (Vega M. 1998; Azizullah A. 2011; Azlan A. 2012). It is noticed that the concentration of lead, iron, nickel and iron were exceeding the standard values allowed by NDWQSM. Moreover, presence of heavy metals in these pools makes these pools water unfit for direct human use yet employment of purification technology such as nanofiltration, reverse osmosis or adsorption could improve its quality. Table 5 here presents the determined concentrations of cations and anions found in reported ex-mining pools.

Table 5: Investigation of Cations and Anions in Ex Mining Pools

\begin{tabular}{ccccccc}
\hline $\begin{array}{c}\text { Ions } \\
(\mathbf{m g} / \mathbf{L})\end{array}$ & $\mathbf{E P 1}$ & $\mathbf{E P 2}$ & $\mathbf{E P 3}$ & $\mathbf{E P 4}$ & $\mathbf{E P 5}$ & $\begin{array}{c}\text { Allowable } \\
\text { Limits [20] } \\
(\mathbf{m g} / \mathbf{L})\end{array}$ \\
\hline $\mathbf{S n}$ & $25.11 \pm 0.86$ & $21.3 \pm 8.58$ & $15.86 \pm 2.25$ & $20.47 \pm 1.58$ & $22.83 \pm 1.96$ & $\mathrm{NA}$ \\
$\mathbf{P b}$ & $0.17 \pm 0.01$ & $0.17 \pm 0.02$ & $0.19 \pm 0.01$ & $0.17 \pm 0.02$ & $0.17 \pm 0.02$ & 0.05 \\
$\mathbf{F e}$ & $0.311 \pm 0.03$ & $0.186 \pm 0.01$ & $0.673 \pm 0.06$ & $1.035 \pm 0.11$ & $1.286 \pm 0.33$ & 0.3 \\
$\mathbf{N i}$ & $0.02 \pm 0.01$ & $0.03 \pm 0.01$ & $0.05 \pm 0.04$ & $0.04 \pm 0.015$ & $0.05 \pm 0.011$ & 0.02 \\
$\mathbf{C r}$ & $\mathrm{ND}$ & $\mathrm{ND}$ & $\mathrm{ND}$ & $\mathrm{ND}$ & $\mathrm{ND}$ & 0.05 \\
$\mathbf{Z n}$ & $\mathrm{ND}$ & $\mathrm{ND}$ & $\mathrm{ND}$ & $\mathrm{ND}$ & $\mathrm{ND}$ & 5 \\
$\mathbf{N a}$ & $2.53 \pm 0.24$ & $1.92 \pm 0.58$ & $4.45 \pm 0.56$ & $4 \pm 0.02$ & $4.18 \pm 0.05$ & 200 \\
$\mathbf{C a}{ }^{2+}$ & $13.23 \pm 0.88$ & $12.86 \pm 2.62$ & $7.77 \pm 0.36$ & $7.8 \pm 0.24$ & $8.61 \pm 0.46$ & 100 \\
$\mathbf{M g}^{2+}$ & $0.44 \pm 0.04$ & $0.89 \pm 0.27$ & $0.8 \pm 0.15$ & $0.84 \pm 0.15$ & $0.73 \pm 0.17$ & 150 \\
$(\mathbf{C l})^{-1}$ & $4.278 \pm 0.19$ & $2.476 \pm 1.20$ & $3.45 \pm 1.32$ & $3.356 \pm$ & $5.032 \pm 0.43$ & 250 \\
$(\mathbf{N O})^{-1}$ & $0.655 \pm 0.1$ & $0.208 \pm 0.105$ & $2.103 \pm 0.37$ & $3.164 \pm 0.78$ & $8.521 \pm 1.38$ & 10 \\
$(\mathbf{P O 4})^{-3}$ & $0.479 \pm 0.03$ & $\mathrm{ND}$ & $\mathrm{ND}$ & $\mathrm{ND}$ & $\mathrm{ND}$ & 0.2 \\
$(\mathbf{S O 4})^{-2}$ & $2.042 \pm 0.16$ & $6.637 \pm 0.92$ & $7.364 \pm 0.54$ & $8.125 \pm 1.94$ & $10.58 \pm 1.40$ & 400 \\
\hline
\end{tabular}

*NA =Not available

*ND=Not Detected

viii. Hardness (as $\left.\mathrm{CaCO}_{3}\right)$

Hardness of ex-mining pools was also investigated here. Table 6 gives the average value of hardness $\left(\mathrm{CaCO}_{3}\right.$ based $)$ over the sampling tenure. During the tenure from July to November, hardness of ex-mining pools here reduced consistently which is believed to be the result of 
dilution due to excessive rain over the tenure as reported by Y.Ouyang et al. as well (Ouyang Y. 2006). It is noted that hardness of pools remains under the standard limits allowed by NDWQSM, which is $200 \mathrm{mg} / \mathrm{L}$ (DWQSM 2010).

Table 6: Calcium Hardness of Ex-Mining Pools

\begin{tabular}{cccccc}
\hline \multicolumn{7}{c}{ Avg. Hardness $\left(\mathbf{m g} / \mathbf{L}\right.$ of $\left.\mathbf{C a C O}_{3}\right)$} & \\
\hline Month & EP1 & EP2 & EP3 & EP4 & EP5 \\
\hline Jul-14 & 42.36 & 35.10 & 20.54 & 27.15 & 28.10 \\
Sep-14 & 35.95 & 40.09 & 26.66 & 25.83 & 28.11 \\
Nov-14 & 26.24 & 31.25 & 20.89 & 15.85 & 17.12 \\
Standard Deviation & \pm 8.11 & \pm 4.43 & \pm 3.43 & \pm 6.19 & \pm 6.3 \\
\hline
\end{tabular}

\section{CONCLUSION}

This study reveals that ex-mining pools investigated in this study have strong potential to be utilized as potable water after viable treatment such as nanofiltration, reverse osmosis or adsorption. Else seasonal effects are significant since during rainy days turbidity and suspended solids are noted to increase due to surface runoff of rainfall water in pools while COD values tend to decrease a little. On the contrary, for dry season, pools shows higher COD values and low turbidity and suspended solids in them. Exmining pools have also shown the significant amount of heavy metal ions in it. Lead, nickel and iron were noted to be in hazardous amount up to $0.19 \pm 0.01 \mathrm{mg} / \mathrm{L}$, $0.05 \pm 0.04 \mathrm{mg} / \mathrm{L}, 1.286 \pm 0.33 \mathrm{mg} / \mathrm{L}$ respectively during the rainy days. Author suggests that further investigation could be carried out to identify more contaminants such as radioactive elements, organic compounds and organic/inorganic metal compounds.

\section{ACKNOWLEDGMENT}

Author is cordially grateful to MyRA funding authority for their financial support (0153AB-J16) and Universiti Teknologi PETRONAS for its technical support and lab facilities. 


\section{REFERENCES}

Abidin, R. D. Z. R. Z. and Unit, E. P. (2004). Water resources management in Malaysia: The way forward. Buletin Ingenieur 22: 810.

Ang L. H. (1994). Problems and prospects of afforestation on sandy tin tailings in Peninsular Malaysia. Journal of Tropical Forest Science 7: 87-105.

Alshaebi F. Y., Yaacob W. Z. W., Samsudin A. R. and Alsabahi E. (2009). Risk assessment at abandoned tin mine in Sungai Lembing, Pahang, Malaysia. Electronic Journal of Geotechnical Engineering 14: 1-9.

Arumugam P. T. (1994). Present utilization and recommendations for management of tin-mine lakes in Malaysia. Inland Waters of Tropical Asia And Australia: Conservation And Management., Schweizerbart'sche

Verlagsbuchhandl, Stuttgart, pp. 265-272.

Ang L. and Ho W. (2002). Afforestation of tin tailings in Malaysia. In 12th International Soil Conservation
Organization Conference, Beijing, 26-31 May, pp. 440-445.

APHA. (2013). Standard Methods for the examination of water and wastewater, Washington, USA: American Public Health Association.

Azizullah A., Khattak M. N. K., Richter P. and Häder D.-P. (2011). Water pollution in Pakistan and its impact on public health-a review. Environment International 37: 479497.

Azlan A., Khoo H. E., Idris M. A., Ismail A. and Razman M. R. (2012). Evaluation of minerals content of drinking water in Malaysia. The Scientific World Journal 2012: 110.

Drinking Water Quality Standard Putrajaya, Malaysia (2010). http://kmam.moh.gov.my/publicuser/drinking-water-qualitystandard.html (accessed 15 Feburary, 2016)

Husaini A. (2012). Water Resources Agenda in Malaysia. In: Malaysia Water Resources Management Forum, Putrajaya, $26^{\text {th }}$ November, pp. 1-61. 
Hinrichsen D. and Tacio H. (2002). The coming freshwater crisis is already here. Finding the Source: The Linkages Between Population and Water, Woodrow Wilson International Center for Scholars, Washington, $\quad$ DC, $\quad$ ESCP Publication, Spring.

Hock L. C. (2008). State of Water Resources in Malaysia. Dialogue on Water Environment Partnership in Asia (WEPA), Ministry of Natural Resources and Environment. 22 Oct, pp. 1-78.

Kundzewicz Z., Mata L., Arnell N. W., Döll P., Jimenez B., Miller K., Oki T., Şen Z. and Shiklomanov I. (2008). The implications of projected climate change for freshwater resources and their management. Hydrological Sciences Journal 53: 3-10.

Lau R. (1999). TED case studies: tin mining in Malaysia-present and future. Trade Environ Database Case Stud 9: 576.

Makwe E. and Chup C. (2013). Seasonal variation in physico-chemical properties of groundwater around Karu abattoir. Ethiopian Journal of
Environmental Studies and

Management 6: 489-497.

Meme F. K., Arimoro F. O. and Nwadukwe F. O. (2014). Analyses of physical and chemical parameters in surface waters nearby a Cement Factory in North Central, Nigeria. Journal of Environmental Protection 5: 826834.

Mumtaz M., Hanif M., Mukhtar H., Ahmed Z. and Usman S. (2010). Evaluation of pollution load of Lahore Canal by quantification of various pollutants through physicochemical characterisation. Environmental Monitoring and Assessment 167: 437-446.

Orji K., Sapari N., Yusof K., Asadpour R. and Olisa E. (2013). Comparative study of water quality of rivers used for raw water supply \& exmining lakes in Perak, Malaysia. IOP Conference Series: Earth and Environmental Science, Malaysia, 5-6 March, pp. 012072, IOP Publishing Ltd.

Ouyang Y., Nkedi-Kizza P., Wu Q., Shinde D. and Huang C. (2006). Assessment of seasonal variations 
in surface water quality. Water Resources 40: 3800-3810.

Pimentel D., Houser J., Preiss E., White O., Fang H., Mesnick L., Barsky T., Tariche S., Schreck J. and Alpert S. (1997). Water resources: agriculture, the environment, and society. BioScience 47: 97-106.

Post D. and Jakeman A. (1995). Impact of rainfall on turbidity and suspended sediment load at five sites on the Murray River between Albury and Swan Hill and possible relationships to catchment attributes. Proc. Int. Congr. on Modelling and Simulation (MODSIM 95) 1: 194-199.

Ramalho R. (2012). Introduction to wastewater treatment processes. Elsevier.

Tansel B. (2008). New technologies for water and wastewater treatment: A survey of recent patents. Recent Patents on Chemical Engineering 1: 17-26.

Vega M., Pardo R., Barrado E. and Debán L. (1998). Assessment of seasonal and polluting effects on the quality of river water by exploratory data analysis. Water research 32: 35813592.

WHO G. (2011). Guidelines for drinkingwater quality. World Health Organization 216: 303-304.

Yusoff F., Shariff M. and Gopinath N. (2006). Diversity of Malaysian aquatic ecosystems and resources. Aquatic Ecosystem Health \& Management 9: 119-135.

Yusof A., Mahat M., Omar N. and Wood A. (2001). Water quality studies in an aquatic environment of disused tin-mining pools and in drinking water. Ecological Engineering 16: 405-414.

Zakaria, S. (2004). Financing in Malaysia's IWRM. NARBO - $1^{s t}$ GM, Indonesia, 24- 26 Feb. http://www.narbo.jp/data/01_event s/materials/gm01_pas_a08_pa.pdf accessed (2-12-2016).

Zalifah M. and Norrakiah A. (2007). Microbiological and physicochemical quality of drinking water. Malaysian Journal of Analytical Sciences 11: 414-420. 